\title{
Article \\ Evaluation of Calcium Application Methods on Delaying Plant Wilting under Water Deficit in Bedding Plants
}

\author{
Suejin Park ${ }^{\dagger}$ and Nicole L. Waterland * \\ Division of Plant and Soil Sciences, West Virginia University, Morgantown, WV 26506, USA; suejinp@ucr.edu \\ * Correspondence: nicole.waterland@mail.wvu.edu \\ + Current address: Department of Botany and Plant Sciences, University of California Riverside, Riverside, \\ CA 92521, USA.
}

check for

updates

Citation: Park, S.; Waterland, N.L. Evaluation of Calcium Application Methods on Delaying Plant Wilting under Water Deficit in Bedding

Plants. Agronomy 2021, 11, 1383.

https: / / doi.org/10.3390/

agronomy 11071383

Received: 6 June 2021

Accepted: 1 July 2021

Published: 8 July 2021

Publisher's Note: MDPI stays neutral with regard to jurisdictional claims in published maps and institutional affiliations.

Copyright: (c) 2021 by the authors. Licensee MDPI, Basel, Switzerland. This article is an open access article distributed under the terms and conditions of the Creative Commons Attribution (CC BY) license (https:/ / creativecommons.org/licenses/by/ $4.0 /)$.
Abstract: Floriculture crops can lose their aesthetic quality due to water deficit during postproduction. Calcium is a secondary messenger in plant stress signaling, and the treatment of calcium has been proposed to alleviate damage by various abiotic stresses. The objective of this research was to evaluate application methods of calcium to delay plant wilting under water deficiency in three species of bedding plants: viola (Viola cornuta), impatiens (Impatiens walleriana), and petunia (Petunia grandiflora). Three application methods were compared including spray, drench, and pre-drench. Calcium was applied as $\mathrm{CaCl}_{2}$ and $\mathrm{Ca}\left(\mathrm{NO}_{3}\right)_{2}$ at three concentrations ranging from 50 to $300 \mathrm{mM}$. The effect of calcium on shelf life was species-dependent, increasing shelf life in viola and impatiens, but not in petunia. Viola showed increased shelf life up to $154 \%$ and $400 \%$ in drench and pre-drench applications, respectively, compared to the control. In impatiens, spray and pre-drench applications delayed wilting symptoms by $53 \%$ and $200 \%$, respectively. Comparing calcium sources, $\mathrm{CaCl}_{2}$ was the most effective as a drench, while $\mathrm{Ca}\left(\mathrm{NO}_{3}\right)_{2}$ pre-drench application effectively delayed wilting. There was no difference between $\mathrm{CaCl}_{2}$ and $\mathrm{Ca}\left(\mathrm{NO}_{3}\right)_{2}$ in spray application. These results provided the optimum application methods to delay plant witling and the potential of calcium application on enhancing water deficit tolerance in floriculture crops.

Keywords: spray; drench; pre-drench; viola; impatiens; petunia; $\mathrm{CaCl}_{2} ; \mathrm{Ca}\left(\mathrm{NO}_{3}\right)_{2}$; shelf life; shelf life extension; osmotic stress; Ca uptake

\section{Introduction}

Recently, the frequency and severity of extreme climate events have increased significantly, becoming the most significant problem and challenge globally. Climate change is expected to lead to more extreme weather environments, including severe drought, which poses a high risk for the agricultural industry [1]. Severe water deficiency causes a reduction in crop productivity by adversely affecting plant growth and reproduction. According to Earth system models, the decline in global vegetation growth and food production due to drought is estimated to be nearly tripled by the end of the 21st century relative to the 20th century [2]. Such a dramatic reduction in global crop yield will ultimately cause food insecurity worldwide.

Floriculture crops are produced to a high quality in greenhouses, but their quality can be compromised during shipping and retailing. In fact, the postproduction periods are considered suboptimal environmental conditions for plants [3]. During retailing, floriculture crops are often placed on display shelves and roadside stands under suboptimal temperatures and irrigations. Consequently, the substrate dries rapidly, causing plant wilting. Sometimes extreme weather, such as high temperature and prolonged exposure to direct sunlight, exacerbates water deficit stress and diminishes the ornamental quality of plants quickly [4]. Crop losses due to these adverse conditions are estimated to be up to $20 \%$ of unsalable crops [5]. Therefore, it is highly desirable to enhance water deficit 
stress tolerance in floriculture crops to maintain their high quality and longevity during the postproduction period.

The potential use of antitranspirants has been proposed to ameliorate water deficit stress impacts in crop production [6,7]. Antitranspirants are chemical compounds that are applied to leaves or substrates to reduce transpirational water loss and improve plant water stress tolerance [8,9]. Various antitranspirants were evaluated in floriculture crops, and some of them were effective in delaying plant wilting [9]. There are two types of antitranspirants. One type of antitranspirants blocks stomata by forming a film on the leaf, and the other type causes the stomata to close by inducing a stress response. Filmforming antitranspirants are sprayed on the plant canopy to block stomata with a physical barrier [7]. This type of antitranspirants effectively reduced transpirational water loss in bedding plants that had a low density of leaf trichomes [9]. The phytohormone, abscisic acid (ABA), is one of the prominent antitranspirants which induces stomatal closure in plants [7]. Application of ABA reduced stomatal conductance quickly and enhanced water deficit tolerance in a wide range of plant species [8-11]. However, side effects of such antitranspirants were documented as well. A film-forming antitranspirant ( $\beta$ pinene polymer) application caused flower damage in various bedding plants [9]. Foliar chlorosis and leaf abscission have been frequently documented as side effects of ABA treatments [12-14]. Therefore, it is strongly desired to develop a new antitranspirant to enhance water deficit tolerance in floriculture crops.

Exogenous calcium application has been suggested as a candidate antitranspirant with fewer side effects on floriculture crops. Calcium is a secondary messenger involved in various physiological and biochemical processes in a plant's stress response [15]. Many experiments have reported that the exogenous application of calcium mitigated the adverse effects of abiotic stresses by regulating osmotic adjustment, photosynthetic efficiency, and antioxidant activities [16-18]. In the aspect of stomatal movements, an increased level of cytosolic calcium induces ion efflux from guard cells and reduces the guard cell volume, closing stomata when plants are exposed to water deficit [19]. Park et al. [20] suggested that exogenous treatment of $\mathrm{CaCl}_{2}$ enhanced water deficit tolerance by promoting stomatal closure and maintaining high relative water content in Viola cornuta without any side effects.

Based on the positive effects of calcium treatment, finding a practical and optimum application method of calcium for floriculture crops is required to reduce crop loss due to water deficit during the postproduction period. The objectives of this research were to (1) evaluate the effect of calcium treatment on three species of annual bedding plants, (2) compare two calcium sources $\left(\mathrm{CaCl}_{2}\right.$ and $\left.\mathrm{Ca}\left(\mathrm{NO}_{3}\right)_{2}\right)$, and (3) identify the effective application methods (spray, drench, and pre-drench) of calcium for each species under water deficit stress.

\section{Materials and Methods}

\subsection{Plant Materials}

Three species of popular bedding plants (Viola cornuta 'Sorbet ${ }^{\circledR}$ XP Yellow', Impatiens walleriana 'Xtreme ${ }^{\mathrm{TM}}$ White', and Petunia grandiflora 'Tritunia ${ }^{\mathrm{TM}}$ Red') were selected in this study to investigate the effect of calcium application to enhance water deficit tolerance. Viola and impatiens are sensitive, and petunia is moderately sensitive to water deficit stress [21]. Seeds of bedding plants were sown in a 288-plug tray, and 4-week-old seedlings were transplanted into $11 \mathrm{~cm}$ pots with soilless media (Sunshine Mix \#1, Sun Gro Horticulture, Agawam, MA, USA). Plants were grown in a greenhouse (Morgantown, WV, USA) under natural irradiance with supplemental lighting of high-pressure sodium lamps (600 W HS200 deep reflector; Hortilux, Pijnacker, The Netherlands). The supplemental lights were turned on when natural radiance fell below $50 \mathrm{~W} \cdot \mathrm{m}^{-2}$. Plants were fertigated with 20N-1.3P-15.8K (Peter Professional Petunia Special; Everris NA, Marysville, OH, USA), except for impatiens (15N-2.2P-12.5K, Peter ${ }^{\circledR}$ Excel Cal-Mag; Everris NA). The fertilizer rate was $200 \mathrm{mg} \cdot \mathrm{L}^{-1}$ nitrogen $(\mathrm{N})$, and it was reduced to $100 \mathrm{mg} \cdot \mathrm{L}^{-1} \mathrm{~N}$ one week before treatment. All bedding plants were subjected to calcium application when they reached a 
marketable stage of at least one open flower per pot. Plants were irrigated with deionized (DI) water to container capacity $12 \mathrm{~h}$ before application. Calcium sources were $\mathrm{CaCl}_{2}$ and $\mathrm{Ca}\left(\mathrm{NO}_{3}\right)_{2}$, and calcium solutions were applied between 0900 to $1000_{\mathrm{HR}}$. Three methods of calcium treatment were evaluated independently.

\subsection{Spray Application}

Plants were grown in the greenhouse with the following environmental conditions. The average daily photosynthetic photon flux density (PPFD) was $180 \mu \mathrm{mol} \cdot \mathrm{m}^{-2} \cdot \mathrm{s}^{-1}$ from 0600 to $2000_{\mathrm{HR}}$. Mean greenhouse temperatures were $22.9 \pm 1.8 / 18.3 \pm 1.7{ }^{\circ} \mathrm{C}$ day $/$ night (mean \pm SD) with a mean relative humidity of 33\%. Calcium was sprayed at 50, 100, and $200 \mathrm{mM}$ with the addition of $0.5 \%$ surfactant (TWEEN ${ }^{\mathrm{TM}}$ 20; Fisher BioReagnets ${ }^{\mathrm{TM}}$, Fisher Scientific, Waltham, MA, USA) on the top and the underside of the plant canopy (about $35 \mathrm{~mL}$ per plant) using a handheld pump sprayer. Deionized water with $0.5 \%$ surfactant was sprayed as a control treatment. Water was withheld immediately after spray application.

\subsection{Drench Application}

The growing conditions were PPFD of $230 \mu \mathrm{mol} \cdot \mathrm{m}^{-2} \cdot \mathrm{s}^{-1}$ from 0600 to $2000_{\mathrm{HR}}$, $22.6 \pm 1.7 / 18.6 \pm 1.4{ }^{\circ} \mathrm{C}$ day /night with a mean relative humidity of $41 \%$. Calcium solutions were drenched at 100, 200, and $300 \mathrm{mM}$ in substrates, and control was drenched with DI water $(60 \mathrm{~mL}$ per pot). Water was withheld immediately after drench application.

\subsection{Pre-Drench Application}

The growing conditions were PPFD of $287 \mu \mathrm{mol} \cdot \mathrm{m}^{-2} \cdot \mathrm{s}^{-1}$ from 0600 to $2000_{\mathrm{HR}}$, $21.8 \pm 2.9 / 17.4 \pm 2.1{ }^{\circ} \mathrm{C}$ day/night with a mean relative humidity of $72 \%$. Deionized water was drenched as control and calcium solutions were drenched at 100, 200, and $300 \mathrm{mM}$ in substrates $\left(60 \mathrm{~mL}\right.$ per pot). Treated plants were fertigated at $100 \mathrm{mg} \cdot \mathrm{L}^{-1} \mathrm{~N}$ for the next three days and subsequently they were exposed to water deficit.

\subsection{Water Deficit Treatment and Measurements}

Treated plants were placed in the greenhouse during water deficit stress by withholding irrigation, and visual wilting status was documented daily. The shelf life was determined by the number of days from the first day of water being withheld until plants showed wilting symptoms. Shelf life data were normalized as shelf life extension (\%), which was calculated with the following equation:

Shelf life extension $(\%)=\frac{\text { shelf life of } C a \text {-treated plant }- \text { shelf life of control }}{\text { shelf life of control }} \times 100$

\subsection{Statistical Analyses}

All experiments were laid in a $3 \times 2 \times 3$ factorial arrangement (species $\times$ calcium source $\times$ concentration) in a randomized complete block design with four replications $(n=4)$ except for petunia in drench application with three replications $(n=3)$. Each plant was analyzed as one replication. Statistical analyses were carried out using the General Linear Model Procedure (PROC GLM) of SAS (version 9.4; SAS Institute, Cary, NC, USA). Shelf life extension was analyzed using analysis of variance (ANOVA) with three main factors: species, calcium source, and concentration. Orthogonal contrasts were used for the pre-planned comparisons among three species (sensitive vs. moderately sensitive species and viola vs. impatiens). Regression analysis was conducted with shelf life and shelf life extension to test significant $(p \leq 0.05)$ linear or quadratic effects of calcium concentration.

\section{Results}

\subsection{Spray Application}

The main effect of species was significant in shelf life extension when spray application was used $(p<0.0001)$ (Table 1). Orthogonal contrasts showed that sensitive species, viola and impatiens, had higher shelf life extension than moderately sensitive species, 
petunia ( $p=0.0007$ ) (Table 1 and Figure 1). Increased shelf life extension was observed in impatiens comparing to viola $(p=0.0001)$ (Table 1 and Figure 1$)$. Calcium spray application in impatiens had $25-46 \%$ of shelf life extension, which was 1.1 to 2.1 days extension compared to control (Figure 1). The other two main effects (calcium source and concentration) and interaction effects showed no difference (Table 1). Shelf life extension was not changed with increasing Ca concentration (50-200 mM) in all three species with spray application (Figure 1), confirming no significant main effect of concentration.

Table 1. Factorial ANOVA on shelf life extension in spray application.

\begin{tabular}{lcccc}
\hline Source of Variance & df & MS & F-Value & $p$-Value \\
\hline Replication & 3 & 1766.7 & 1.7 & 0.1732 \\
Species (A) & 2 & $15,334.7$ & 15.0 & $<0.0001$ \\
$\quad$ Sensitive (Viola and & & & & \\
Impatiens) vs. & 1 & $13,417.4$ & 13.1 & 0.0007 \\
Moderate (Petunia) & 1 & $17,252.1$ & 16.9 & 0.0001 \\
$\quad$ Viola vs. Impatiens & 1 & 67.5 & 0.1 & 0.7984 \\
Calcium source (B) & 2 & 911.7 & 0.9 & 0.4166 \\
Concentration (C) & 2 & 1125.8 & 1.1 & 0.3406 \\
$\mathrm{~A}^{*} \mathrm{~B}$ & 4 & 554.9 & 0.5 & 0.7053 \\
$\mathrm{~A}^{*} \mathrm{C}$ & 2 & 139.7 & 0.1 & 0.8727 \\
$\mathrm{~B}^{*} \mathrm{C}$ & 4 & 345.6 & 0.3 & 0.8512 \\
$\mathrm{~A}^{*} \mathrm{~B}{ }^{*} \mathrm{C}$ & 51 & 1023.3 & & \\
Error & & & & \\
\hline
\end{tabular}

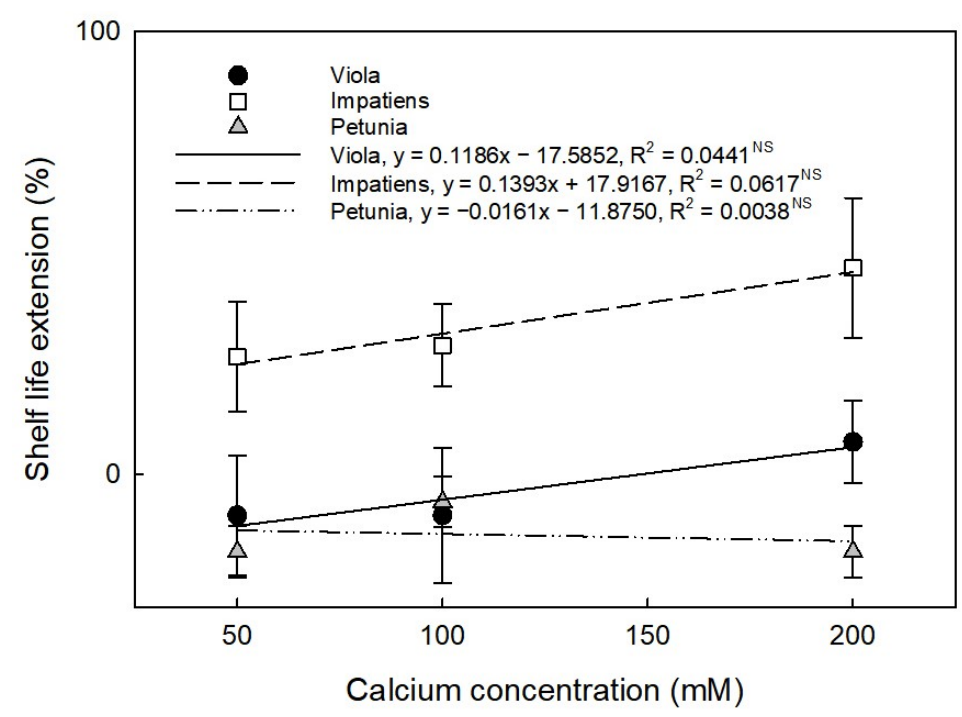

Figure 1. Influence of calcium concentration on shelf life extension of $V$. cornuta (viola), I. walleriana (impatiens), and P. grandiflora (petunia) in spray application. Each data point represents the mean of shelf life extension from $\mathrm{CaCl}_{2}$ and $\mathrm{Ca}\left(\mathrm{NO}_{3}\right)_{2}$, but the analysis was performed with all data $(\mathrm{n}=8)$. Bars represent standard error. NS, nonsignificant.

Shelf life of impatiens increased linearly as the concentration of $\mathrm{CaCl}_{2}$ and $\mathrm{Ca}\left(\mathrm{NO}_{3}\right)_{2}$ increased (Figure 2). One hundred millimolar increase of $\mathrm{CaCl}_{2}$ and $\mathrm{Ca}\left(\mathrm{NO}_{3}\right)_{2}$ extended impatiens shelf life by 0.6 and 0.9 day, respectively $\left(p=0.0052\right.$ and $0.0439, \mathrm{R}^{2}=0.4382$ and 0.2594 , respectively). The effect of $\mathrm{CaCl}_{2}$ and $\mathrm{Ca}\left(\mathrm{NO}_{3}\right)_{2}$ concentrations on shelf life did not fit any tested regression models in viola and petunia (Figure 2). 


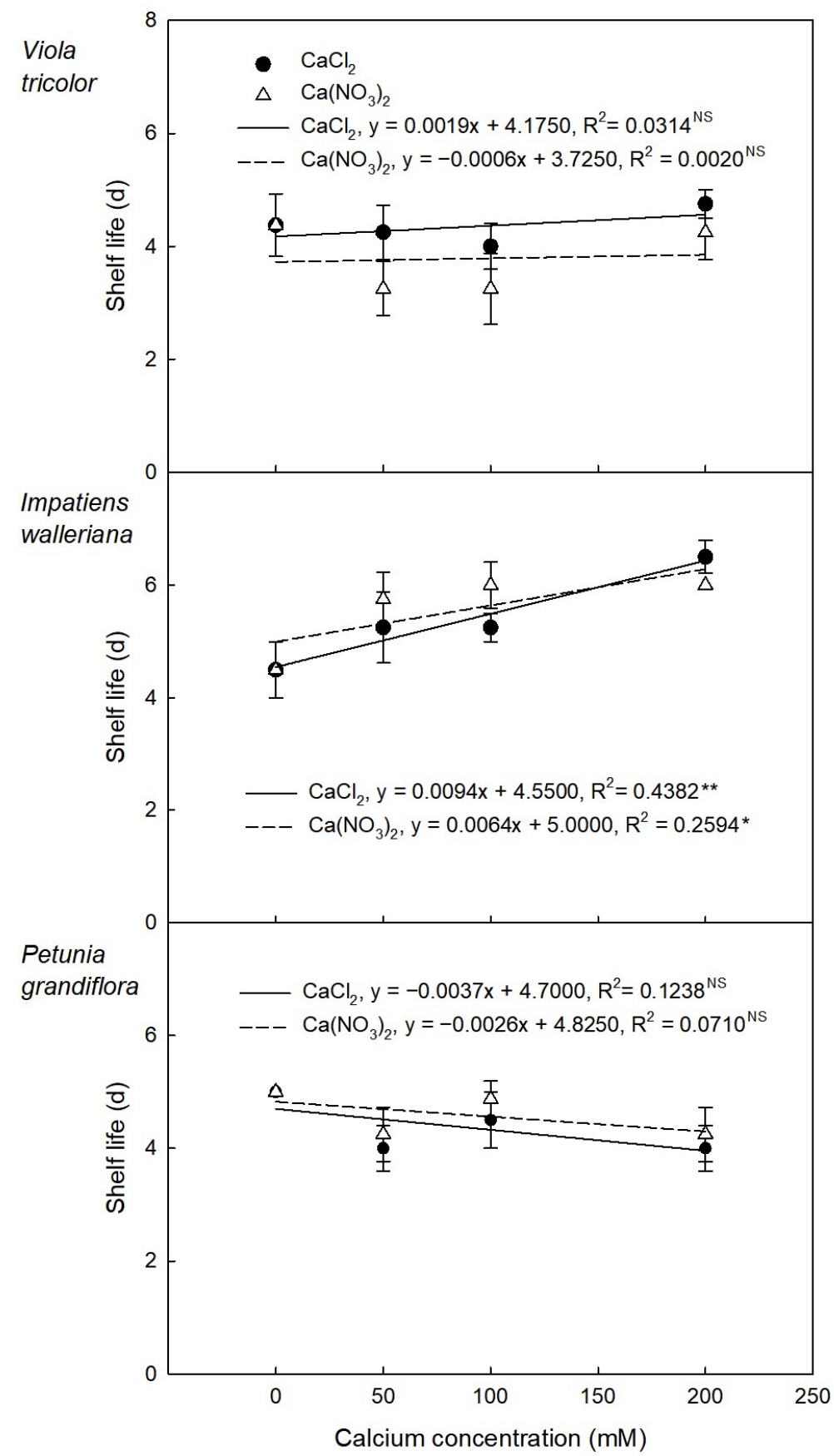

Figure 2. Influence of concentrations of $\mathrm{CaCl}_{2}$ and $\mathrm{Ca}\left(\mathrm{NO}_{3}\right)_{2}$ on shelf life of $V$. cornuta (viola), $I$. walleriana (impatiens), and P. grandiflora (petunia) in spray application. Each data point represents the mean of shelf life, but the analysis was performed with all data $(n=4)$. Bars represent standard error. NS, nonsignificant; ${ }^{*}$, significant at $p \leq 0.05 ;{ }^{* *}$, significant at $p \leq 0.01$.

\subsection{Drench Application}

The main effect of species was significant in shelf life extension in drench application $(p<0.0001)$ (Table 2). However, there was no difference between sensitive and moderately sensitive species $(p=0.6817)$. Within sensitive species, drench application was more effective in viola compared to impatiens $(p<0.0001)$ (Table 2 and Figure 3$)$. The interaction effect (species $\times$ concentration) was significant in drench application $(p=0.0188)$ (Table 2). Viola showed a linear shelf life extension response to Ca concentration $(p=0.0067$ and $\mathrm{R}^{2}=0.2896$ ) (Figure 3). According to the linear regression model, viola shelf life extension was increased up to $142 \%$ (3.3 days of extension) at $300 \mathrm{mM}$ calcium drench application 
(Figure 3). However, Ca drench treatment did not increase the shelf life extension of impatiens and petunia ( $p=0.5585$ and 0.1806 , respectively). There was no significance in other main and interaction effects (Table 2).

Table 2. Factorial ANOVA on shelf life extension in drench application.

\begin{tabular}{lcccc}
\hline Source of Variance & df & MS & F-Value & $p$-Value \\
\hline Replication & 3 & 3862.1 & 2.6 & 0.0668 \\
Species (A) & 2 & $46,798.2$ & 31.0 & $<0.0001$ \\
$\quad$ Sensitive (Viola and Impatiens) vs. & 1 & 257.2 & 0.2 & 0.6817 \\
Moderate (Petunia) $\quad$ Viola vs. Impatiens & 1 & $93,339.1$ & 61.8 & $<0.0001$ \\
Calcium source (B) & 1 & 9.6 & 0.0 & 0.9366 \\
Concentration (C) & 2 & 4796.3 & 3.2 & 0.0512 \\
$\mathrm{~A}^{*} \mathrm{~B}$ & 2 & 381.8 & 0.3 & 0.7776 \\
$\mathrm{~A}^{*} \mathrm{C}$ & 4 & 4974.7 & 3.3 & 0.0188 \\
$\mathrm{~B}^{*} \mathrm{C}$ & 2 & 3492.3 & 2.3 & 0.1106 \\
$\mathrm{~A}^{*} \mathrm{~B}^{*} \mathrm{C}$ & 4 & 2615.0 & 1.7 & 0.1595 \\
Error & 45 & 1509.5 & & \\
\hline
\end{tabular}

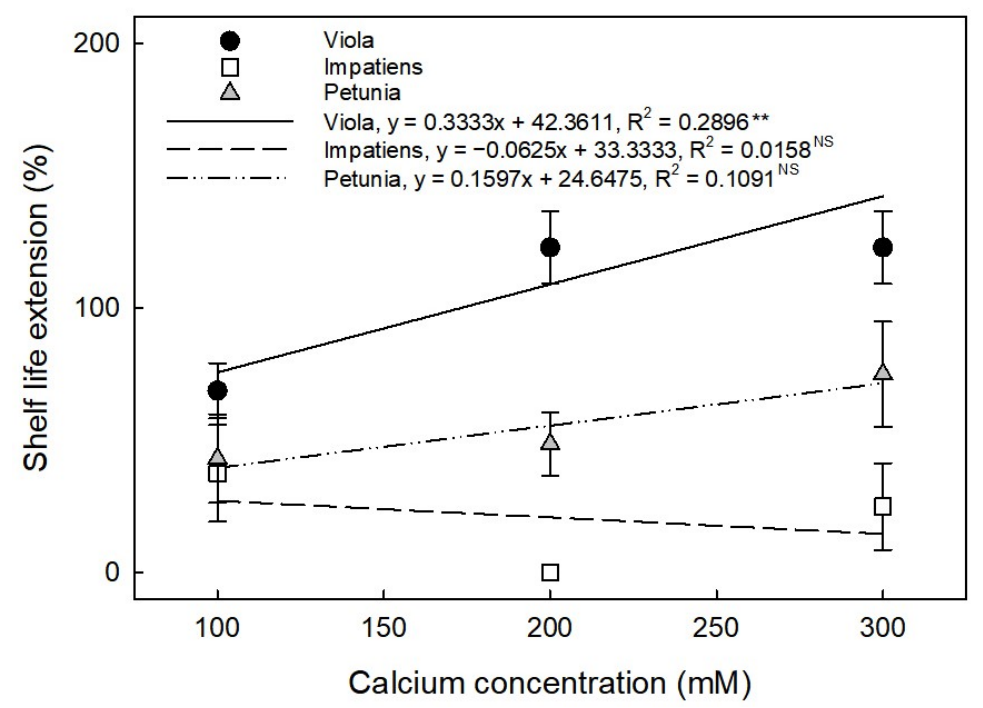

Figure 3. Influence of calcium concentration on shelf life extension of $V$. cornuta (viola), I. walleriana (impatiens), and P. grandiflora (petunia) in drench application. Each data point represents the mean of shelf life extension from $\mathrm{CaCl}_{2}$ and $\mathrm{Ca}\left(\mathrm{NO}_{3}\right)_{2}$, but the analysis was performed with all data $(\mathrm{n}=8$ for viola and impatiens and $\mathrm{n}=6$ for petunia). Bars represent standard error. NS, nonsignificant; **, significant at $p \leq 0.01$.

In viola, Ca drench treatment was effective on increasing shelf life (Figure 4). Shelf life increased linearly with increasing $\mathrm{CaCl}_{2}$ concentration by up to 5.5 days $(p<0.0001$ and $\left.\mathrm{R}^{2}=0.8232\right)$. The regression model showed an increase of $100 \mathrm{mM} \mathrm{CaCl}_{2}$ extended shelf life by 1.1 days. With $\mathrm{Ca}\left(\mathrm{NO}_{3}\right)_{2}$, the concentration effect on shelf life extension fit a quadratic rather than the linear model. Shelf life was gradually increased by 4.8 days between 0 and $200 \mathrm{mM}$ until plateaued at $300 \mathrm{mM} \mathrm{Ca}\left(\mathrm{NO}_{3}\right)_{2}\left(p<0.0001\right.$ and $\left.\mathrm{R}^{2}=0.8991\right)$. Drench application of $\mathrm{Ca}\left(\mathrm{NO}_{3}\right)_{2}$ at 200 and $300 \mathrm{mM}$ extended shelf life by 2.5 days compared to the control. Impatiens and petunia were not affected by the concentration of $\mathrm{CaCl}_{2}$ and $\mathrm{Ca}\left(\mathrm{NO}_{3}\right)_{2}$ treatments (Figure 4). 


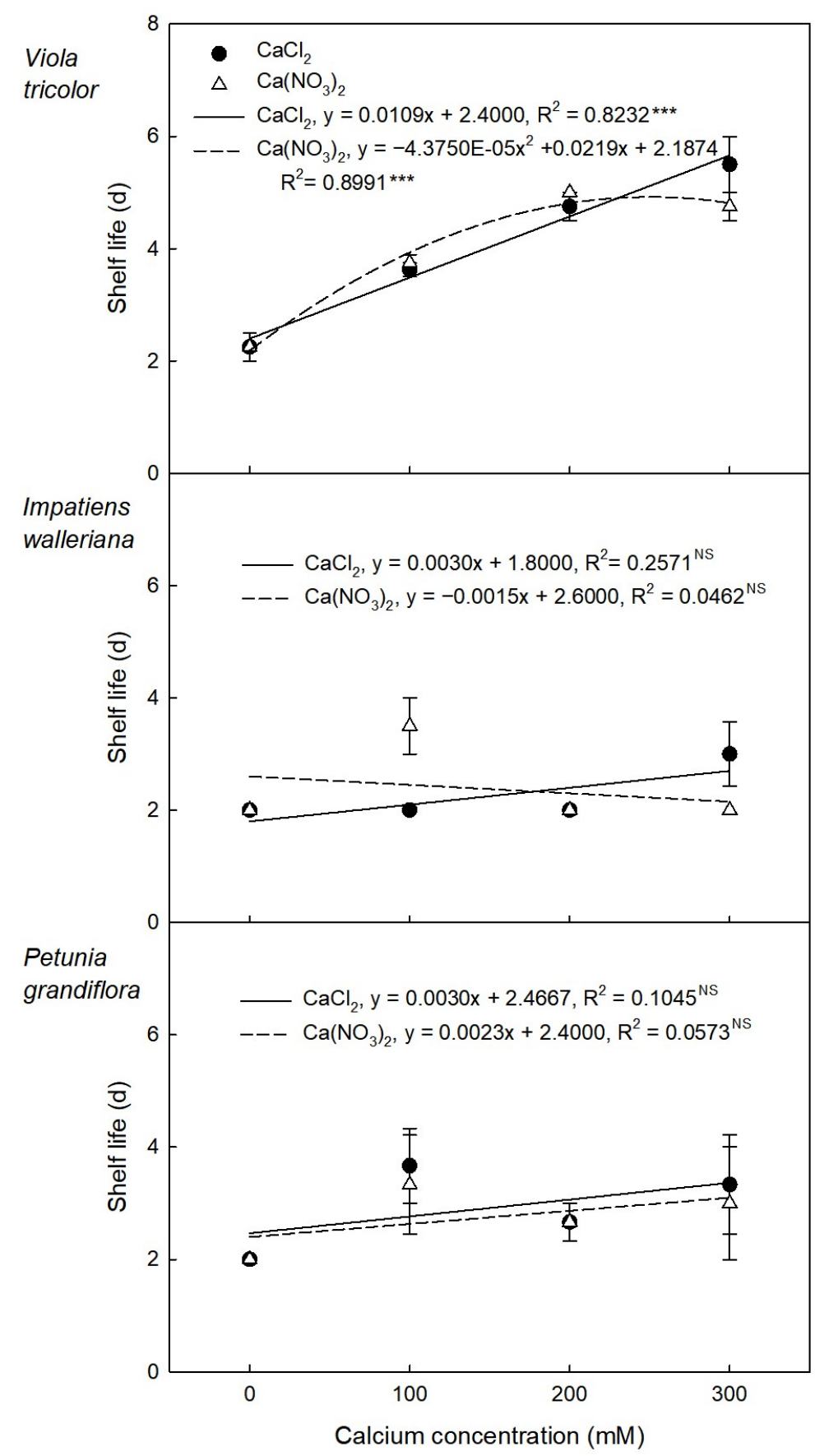

Figure 4. Influence of concentrations of $\mathrm{CaCl}_{2}$ and $\mathrm{Ca}\left(\mathrm{NO}_{3}\right)_{2}$ on shelf life of $V$. cornuta (viola), $I$. walleriana (impatiens), and P. grandiflora (petunia) in drench application. Each data point represents the mean of shelf life, but the analysis was performed with all data $(n=4$ for viola and impatiens and $\mathrm{n}=3$ for petunia). Bars represent standard error. NS, nonsignificant; ${ }^{* * *}$, significant at $p \leq 0.001$.

\subsection{Pre-Drench Application}

The factorial ANOVA table showed that species and concentration effects were significant $(p<0.0001)$ in shelf life extension of pre-drench application (Table 3$)$. Sensitive species (viola and impatiens) had higher shelf life extension than petunia $(p<0.0001)$ and viola had a higher shelf life extension than impatiens $(p<0.0001)$ (Table 3 and Figure 5). The main effect of concentration and the interaction effect between species and concentration were significant $(p<0.0001$ and $p=0.0001$, respectively) (Table 3). Shelf life extension was increased as calcium concentration increased in viola $\left(p<0.0001\right.$ and $\left.R^{2}=0.5765\right)$, but increasing calcium concentration did not prolong shelf life in impatiens and petunia 
( $p=0.1795$ and 0.2334 , and $R^{2}=0.0804$ and 0.0639 , respectively) (Figure 5). The regression model showed an increase of $100 \mathrm{mM}$ calcium extended shelf life by $106 \%$ or a 1.1 day extension in viola. The effects of calcium source and other interactions were not significant (Table 3).

Table 3. Factorial ANOVA on shelf life extension in pre-drench application.

\begin{tabular}{lcccc}
\hline Source of Variance & df & MS & F-Value & $p$-Value \\
\hline Replication & 3 & 1774.7 & 0.6 & 0.6432 \\
Species (A) & 2 & $431,589.5$ & 136.4 & $<0.0001$ \\
$\quad$ Sensitive (Viola and Impatiens) vs. & 1 & $622,345.7$ & 196.7 & $<0.0001$ \\
Moderate (Petunia) & 1 & $240,833.3$ & 76.1 & $<0.0001$ \\
$\quad$ Viola vs. Impatiens & 1 & 7469.1 & 2.4 & 0.1306 \\
Calcium source (B) & 2 & $48,962.2$ & 15.5 & $<0.0001$ \\
Concentration (C) & 2 & 2330.2 & 0.7 & 0.4838 \\
$\mathrm{~A}^{*} \mathrm{~B}$ & 4 & $23,059.4$ & 7.3 & 0.0001 \\
$\mathrm{~A}^{*} \mathrm{C}$ & 2 & 6670.5 & 2.1 & 0.1319 \\
$\mathrm{~B}^{*} \mathrm{C}$ & 4 & 7052.5 & 2.2 & 0.0788 \\
$\mathrm{~A}^{*} \mathrm{~B}^{*} \mathrm{C}$ & 51 & 3163.6 & & \\
Error & & &
\end{tabular}

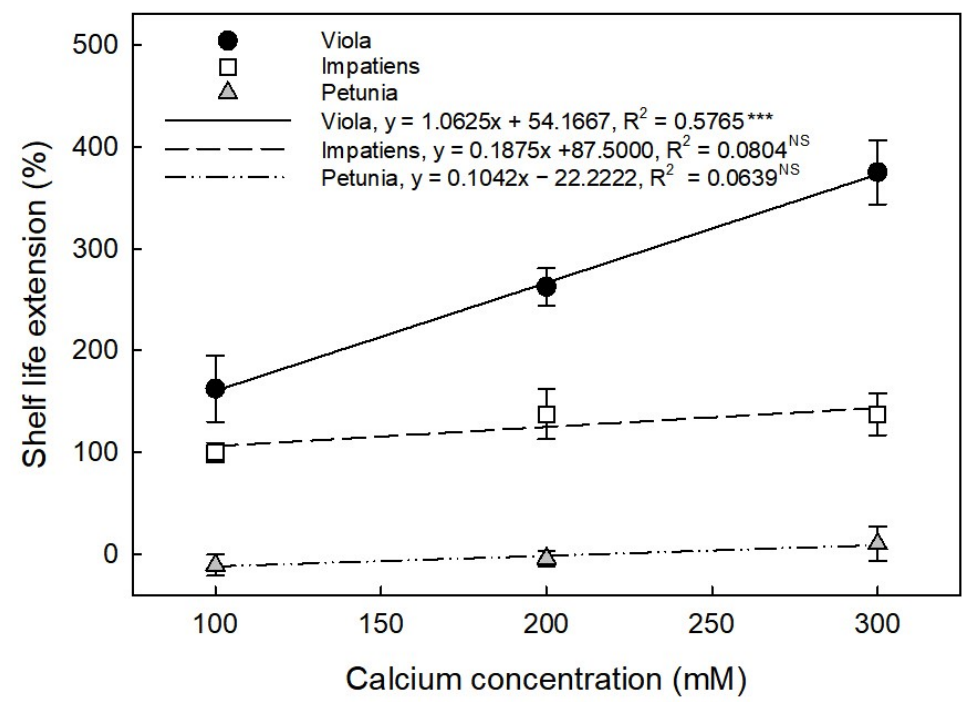

Figure 5. Influence of calcium concentration on shelf life extension of V. cornuta (viola), I. walleriana (impatiens), and P. grandiflora (petunia) in pre-drench application. Each data point represents the mean of shelf life extension from $\mathrm{CaCl}_{2}$ and $\mathrm{Ca}\left(\mathrm{NO}_{3}\right)_{2}$, but the analysis was performed with all data $(\mathrm{n}=8)$. Bars represent standard error. NS, nonsignificant; ${ }^{* * *}$, significant at $p \leq 0.001$.

In pre-drench application, shelf life was linearly increased in response to both $\mathrm{CaCl}_{2}$ and $\mathrm{Ca}\left(\mathrm{NO}_{3}\right)_{2}$ concentration in viola $\left(p<0.0001\right.$, and $\mathrm{R}^{2}=0.8577$ and 0.7685 , respectively) (Figure 6). Viola showed the longest shelf life of 5.0 and 4.5 days at $300 \mathrm{mM}$ of $\mathrm{CaCl}_{2}$ and $\mathrm{Ca}\left(\mathrm{NO}_{3}\right)_{2}$, respectively. Shelf life was extended by 1.3 and 1.1 days with $100 \mathrm{mM}$ increases of $\mathrm{CaCl}_{2}$ and $\mathrm{Ca}\left(\mathrm{NO}_{3}\right)_{2}$ respectively. Impatiens responded linearly to $\mathrm{CaCl}_{2}$ concentration ( $p=0.0005$ and $\left.\mathrm{R}^{2}=0.5904\right)$, increasing shelf life by 0.8 day per $100 \mathrm{mM}$ of $\mathrm{CaCl}_{2}$. Predrench application of $\mathrm{Ca}\left(\mathrm{NO}_{3}\right)_{2}$ showed a quadratic response in impatiens $(p<0.0001$ and $\mathrm{R}^{2}=0.8556$ ). Shelf life of impatiens treated with $\mathrm{Ca}\left(\mathrm{NO}_{3}\right)_{2}$ was increased by 6.0 days at $200 \mathrm{mM}$, followed by a decrease at $300 \mathrm{mM}$ (Figure 6). Impatiens had the highest shelf life treated with $\mathrm{Ca}\left(\mathrm{NO}_{3}\right)_{2}$ at $200 \mathrm{mM}$. Similar to spray and drench applications, shelf life was not affected by pre-drench application in petunia. 


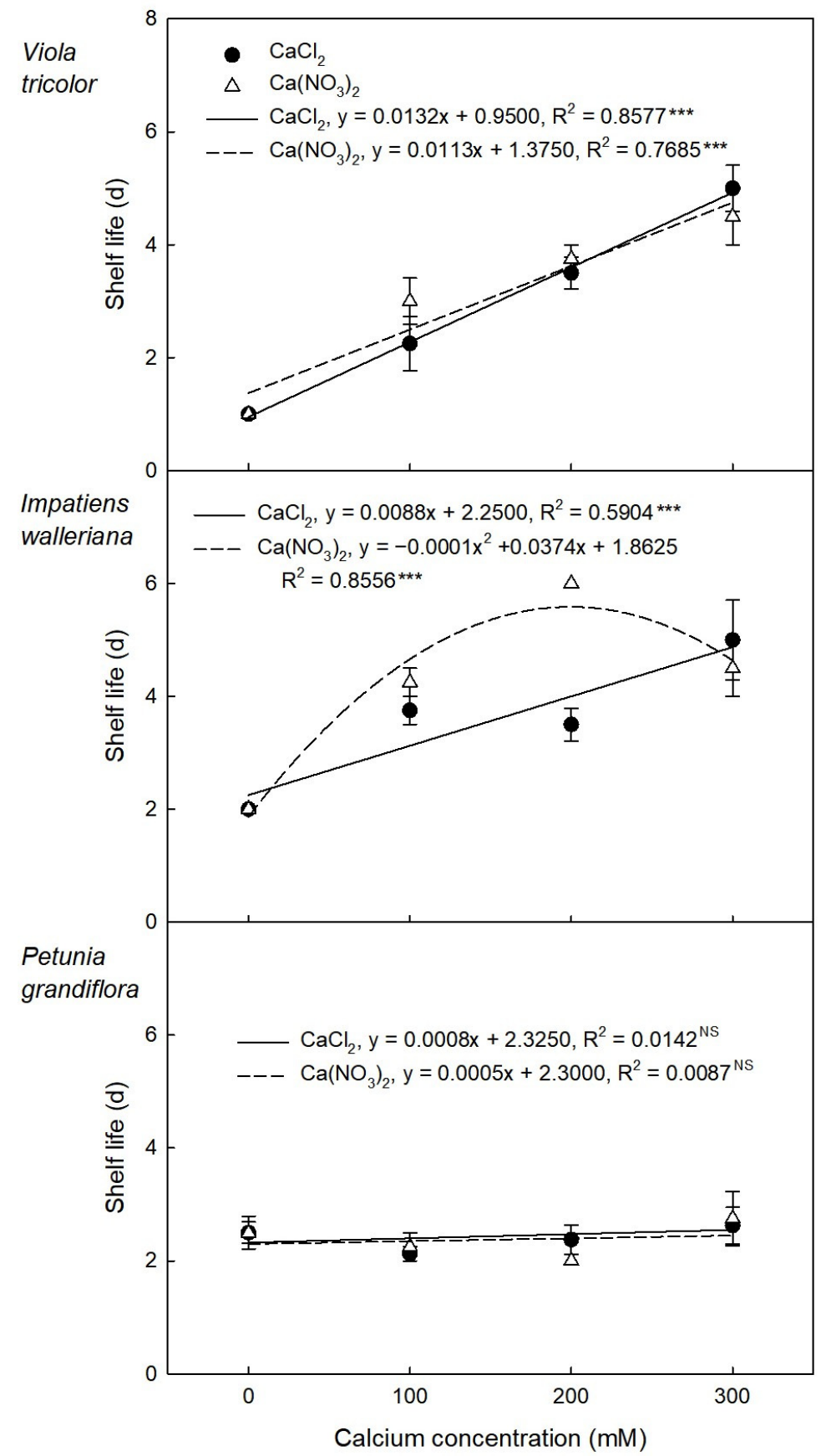

Figure 6. Influence of concentrations of $\mathrm{CaCl}_{2}$ and $\mathrm{Ca}\left(\mathrm{NO}_{3}\right)_{2}$ on shelf life of $V$. cornuta (viola), I. walleriana (impatiens), and P. grandiflora (petunia) in pre-drench application. Each data point represents the mean of shelf life, but the analysis was performed with all data $(n=4)$. Bars represent standard error. NS, nonsignificant; ${ }^{* * *}$, significant at $p \leq 0.001$.

\section{Discussion}

The efficacy of Ca treatment methods on enhancing water deficit stress tolerance appeared to be species-dependent. Plant wilting was delayed in viola with drench and predrench applications, while spray and pre-drench applications were effective for impatiens. However, none of methods was effective in petunia.

Differences in response to the application methods might be associated with the mode of action of treatment methods. Drench application with a high concentration of chemical solutions reduces the soil water potential and induces osmotic stress to plants [20]. Osmotic stress activates similar mechanisms and physiological changes of water deficit 
stress [22-24]. $\mathrm{CaCl}_{2}$-induced osmotic stress has been shown to rapidly trigger stomatal closure within $4 \mathrm{hrs}$ after treatment [20]. The early osmotic stress event could help plants reduce transpirational water loss and delay wilting during the subsequent water deficit stress. Pre-drench also causes osmotic stress to plants, but the following irrigation might alleviate its impact. Inhibited leaf gas exchange parameters, such as photosynthesis, transpiration, and stomatal conductance, by salt/osmotic stresses, recovered after the normal irrigation in Spinacia oleracea [25], V. cornuta [20], and Abelmoschus esculentus [26]. Especially in $\mathrm{CaCl}_{2-}$ treated $V$. cornuta, the subsequent irrigation increased stomatal conductance gradually and fully restored it within four days after osmotic treatment [20]. The resumed transpiration might attribute to calcium uptake and distribution, leading to high Ca contents in plants. Therefore, the positive impacts of pre-drench application on enhancing water deficit stress may result from chemical solution-induced osmotic stress and/or increased Ca uptake in plants.

The spray application was effective only on impatiens. Plants can absorb mineral nutrients sprayed on their leaves, and in some cases, this method has advantages over the nutrient application to the soil [27]. It is possible to speculate that increased Ca uptake by spray or pre-drench applications may enhance water deficit tolerance in impatiens. In this study, the pre-drench application showed $75-200 \%$ extension of shelf life, while the spray application had $18-53 \%$ extension of shelf life. Pre-drench applications may have higher Ca uptake than spray due to a higher calcium solution concentration and/or the three-day watering period between application and water deficit. During this period, plants might absorb a higher amount of calcium and distribute it within the whole plant, resulting in delayed wilting symptoms in impatiens. In addition, Murillo-Amador et al. [28] addressed that Ca spray application increased chlorophyll fluorescence, but it did not alleviate the adverse effects of salt stress in Vigna unguiculata. Thus, pre-drench would be the most effective method for Ca uptake to increase water stress tolerance in impatiens.

Regression analysis indicated that shelf life showed a linear or quadratic response to the concentration of $\mathrm{CaCl}_{2}$ and $\mathrm{Ca}\left(\mathrm{NO}_{3}\right)_{2}$, respectively. In viola treated with drench application, $300 \mathrm{mM} \mathrm{CaCl}$ had higher shelf life than $300 \mathrm{mM} \mathrm{Ca}\left(\mathrm{NO}_{3}\right)_{2}$. Chloride was suggested to induce stomatal closure by activating an ABA-dependent pathway in Vicia faba under salt stress [29]. In this study, $\mathrm{Cl}^{-}$from $\mathrm{CaCl}_{2}$ might play an important role as an osmotic stress inducer to stimulate stress mechanisms, extending the shelf life in viola. In contrast, pre-drench application of $\mathrm{Ca}\left(\mathrm{NO}_{3}\right)_{2}$ was effective with the highest shelf life of 6 days at $200 \mathrm{mM}$ compared to $\mathrm{CaCl}_{2}$ in impatiens. Previous studies suggested that nitrate is the most dominant counter anion to stimulate $\mathrm{Ca}$ uptake and movement by plants [30-32]. In pre-drench application, nitrate from $\mathrm{Ca}\left(\mathrm{NO}_{3}\right)_{2}$ appeared to increase Ca uptake and translocation, leading to higher shelf life in impatiens under water deficiency. This result supports that increased Ca uptake by pre-drench application would be more effective in enhancing water stress tolerance than drench-induced osmotic stress in impatiens.

The species-dependent responses to $\mathrm{Ca}$ application methods might be related to the level of water deficit tested species. Calcium treatments delayed plant wilting and extended shelf life in the extremely sensitive species (viola and impatiens), while none of the methods was influential in the moderately tolerant species (petunia). Ca-induced osmotic stress or increased Ca uptake would not be efficient to enhance water deficit tolerance in species with high tolerance traits to water stress. According to Villarino et al. [33], Viola tricolor, I. walleriana, and Petunia $\times$ hybrida have been characterized as extremely sensitive, moderately sensitive, and highly tolerant species to the high saline substrate, respectively. The different levels of salt stress tolerance might result in different responses to drench application. The higher efficacy of drench application was shown in the most sensitive species, viola compared to impatiens and petunia, to enhance water stress tolerance.

\section{Conclusions}

The efficacy of three calcium application methods was evaluated on enhancing temporary water deficit stress tolerance in three species of annual bedding plants. Plant wilting 
of viola was delayed by drench and pre-drench applications, while spray and pre-drench applications were effective in impatiens. Floriculture crops treated with Ca could maintain the aesthetic quality during the postproduction period because of shelf life extension resulted from increased temporary water deficit stress tolerance. However, the tested plants responded to the Ca treatment methods in a species-dependent manner, probably due to the different salt/osmotic stress tolerance levels. Drench application effectively delayed wilting in the susceptible species (viola), while pre-drench application delayed wilting in the susceptible and moderately sensitive species (viola and impatiens). The most tolerant species did not show enhanced water deficit stress tolerance by any Ca applications. Our results suggested that $\mathrm{CaCl}_{2}$ played a role as an osmotic stress inducer in the drench application and $\mathrm{Ca}\left(\mathrm{NO}_{3}\right)_{2}$ as a $\mathrm{Ca}$ uptake helper in the pre-drench application. Floriculture growers should survey the salt stress sensitivity of their crops before choosing an appropriate application method to maximize the efficacy of Ca application. Additionally, for susceptible species, it would be necessary to compare Ca drench and pre-drench applications under the same environmental conditions to find out the better method since the evaluation of $\mathrm{Ca}$ application methods was performed independently in this experiment. In this study, a high concentration of pure Ca was used. Finding alternative and cheaper Ca sources may help make this application more economical and practical.

Author Contributions: Conceptualization, S.P. and N.L.W.; methodology, S.P. and N.L.W.; software, S.P.; validation, S.P.; formal analysis, S.P.; investigation, S.P.; resources, N.L.W.; data curation, S.P.; writing—original draft preparation, S.P.; writing—review and editing, S.P. and N.L.W.; visualization, S.P.; supervision, N.L.W.; project administration, N.L.W.; funding acquisition, N.L.W. All authors have read and agreed to the published version of the manuscript.

Funding: Salaries and research support were provided in part by state and federal funds appropriated to the West Virginia Agricultural and Forestry Experiment Station, West Virginia University. Scientific Article, No. 3406 of the West Virginia Agricultural and Forestry Experiment Station, Morgantown, WV.

Institutional Review Board Statement: Not applicable.

Informed Consent Statement: Not applicable.

Acknowledgments: We thank PanAmerican Seed and Syngenta Flowers for their donation of plant material.

Conflicts of Interest: The authors declare no conflict of interest.

\section{References}

1. Farooq, M.; Wahid, A.; Kobayashi, N.; Fujita, D.; Basra, S. Plant drought stress: Effects, mechanisms and management. Agron. Sustain. Dev. 2009, 29, 153-188. [CrossRef]

2. Xu, C.; McDowell, N.G.; Fisher, R.A.; Wei, L.; Sevanto, S.; Christoffersen, B.O.; Weng, E.; Middleton, R.S. Increasing impacts of extreme droughts on vegetation productivity under climate change. Nat. Clim. Chang. 2019, 9, 948-953. [CrossRef]

3. Ferrante, A.; Trivellini, A.; Scuderi, D.; Romano, D.; Vernieri, P. Post-production physiology and handling of ornamental potted plants. Postharvest Biol. Technol. 2015, 100, 99-108. [CrossRef]

4. Raudales, R.; Pundt, L. Maintaining High-Quality Plants in Retail Settings. e-GRO Alert 2016, 5, 1-6.

5. Healy, W. Piles of money. Grow. Mag. 2009, 72, 42-46.

6. Pandey, P.; Sharma, R.; Neelkanthe, S. Climate change: Combating drought with antitranspirants and super absorbent. Plant Arch. 2017, 17, 1146-1156.

7. Mphande, W.; Kettlewell, P.S.; Grove, I.G.; Farrell, A.D. The potential of antitranspirants in drought management of arable crops: A review. Agric. Water Manag. 2020, 236, 106143. [CrossRef]

8. Waterland, N.L.; Finer, J.J.; Jones, M.L. Abscisic acid applications decrease stomatal conductance and delay wilting in droughtstressed chrysanthemums. HortTechnology 2010, 20, 896-901. [CrossRef]

9. Park, S.; Mills, S.A.; Moon, Y.; Waterland, N.L. Evaluation of antitranspirants for enhancing temporary water stress tolerance in bedding plants. HortTechnology 2016, 26, 444-452. [CrossRef]

10. Franks, P.J.; Farquhar, G.D. The effect of exogenous abscisic acid on stomatal development, stomatal mechanics, and leaf gas exchange in Tradescantia virginiana. Plant Physiol. 2001, 125, 935-942. [CrossRef]

11. Kim, J.; van Iersel, M.W. Abscisic acid drenches can reduce water use and extend shelf life of Salvia splendens. Sci. Hortic. 2011, 127, 420-423. [CrossRef] 
12. Agehara, S.; Leskovar, D.I. Characterizing concentration effects of exogenous abscisic acid on gas exchange, water relations, and growth of muskmelon seedlings during water stress and rehydration. J. Am. Soc. Hortic. Sci. 2012, 137, 400-410. [CrossRef]

13. Astacio, M.G.; van Iersel, M.W. Determining the effects of abscisic acid drenches on evapotranspiration and leaf gas exchange of tomato. HortScience 2011, 46, 1512-1517. [CrossRef]

14. Waterland, N.L.; Finer, J.J.; Jones, M.L. Benzyladenine and gibberellic acid application prevents abscisic acid-induced leaf chlorosis in pansy and viola. HortScience 2010, 45, 925-933. [CrossRef]

15. Ranty, B.; Aldon, D.; Cotelle, V.; Galaud, J.-P.; Thuleau, P.; Mazars, C. Calcium sensors as key hubs in plant responses to biotic and abiotic stresses. Front. Plant Sci. 2016, 7, 327. [CrossRef] [PubMed]

16. Shoresh, M.; Spivak, M.; Bernstein, N. Involvement of calcium-mediated effects on ROS metabolism in the regulation of growth improvement under salinity. Free Radic. Biol. Med. 2011, 51, 1221-1234. [CrossRef] [PubMed]

17. Tan, W.; wei Meng, Q.; Brestic, M.; Olsovska, K.; Yang, X. Photosynthesis is improved by exogenous calcium in heat-stressed tobacco plants. J. Plant Physiol. 2011, 168, 2063-2071. [CrossRef]

18. Upadhyaya, H.; Panda, S.K.; Dutta, B.K. $\mathrm{CaCl}_{2}$ improves post-drought recovery potential in Camellia sinensis (L) O. Kuntze. Plant Cell Rpt. 2011, 30, 495-503. [CrossRef]

19. Roelfsema, M.R.G.; Hedrich, R.; Geiger, D. Anion channels: Master switches of stress responses. Trends Plant Sci. 2012, 17, 221-229. [CrossRef]

20. Park, S.; Moon, Y.; Waterland, N.L. Treatment with Calcium Chloride Enhances Water Deficit Stress Tolerance in Viola (Viola cornuta). HortScience 2020, 55, 882-887. [CrossRef]

21. Selection and Use of Stress-Tolerant Bedding Plants for the Landscape. Available online: https://content.ces.ncsu.edu/selectionand-use-of-stress-tolerant-bedding-plants-for-the-landscape (accessed on 9 May 2021).

22. Bartels, D.; Sunkar, R. Drought and salt tolerance in plants. Crit. Rev. Plant Sci. 2005, 24, 23-58. [CrossRef]

23. Wang, W.; Vinocur, B.; Altman, A. Plant responses to drought, salinity and extreme temperatures: Towards genetic engineering for stress tolerance. Planta 2003, 218, 1-14. [CrossRef]

24. Zhang, J.; Jia, W.; Yang, J.; Ismail, A.M. Role of ABA in integrating plant responses to drought and salt stresses. Field Crop. Res. 2006, 97, 111-119. [CrossRef]

25. Delfine, S.; Alvino, A.; Villani, M.C.; Loreto, F. Restrictions to carbon dioxide conductance and photosynthesis in spinach leaves recovering from salt stress. Plant Physiol. 1999, 119, 1101-1106. [CrossRef] [PubMed]

26. Azeem, A.; Wu, Y.; Xing, D.; Javed, Q.; Ullah, I. Photosynthetic response of two okra cultivars under salt stress and re-watering. J. Plant Interact. 2017, 12, 67-77. [CrossRef]

27. Taiz, L.; Zeiger, E. Plant Physiology, 5th ed.; Sinauer: Sunderland, MA, USA, 2010; pp. 118-119.

28. Murillo-Amador, B.; Jones, H.G.; Kaya, C.; Aguilar, R.L.; García-Hernández, J.L.; Troyo-Diéguez, E.; Ávila-Serrano, N.Y.; Rueda-Puente, E. Effects of foliar application of calcium nitrate on growth and physiological attributes of cowpea (Vigna unguiculata L. Walp.) grown under salt stress. Environ. Exp. Bot. 2006, 58, 188-196. [CrossRef]

29. Geilfus, C.M.; Mithöfer, A.; Ludwig-Müller, J.; Zörb, C.; Muehling, K.H. Chloride-inducible transient apoplastic alkalinizations induce stomata closure by controlling abscisic acid distribution between leaf apoplast and guard cells in salt-stressed Vicia faba. New Phytol. 2015, 208, 803-816. [CrossRef]

30. Kirkby, E. Maximizing calcium uptake by plants. Commun. Soil Sci. Plant Anal. 1979, 10, 89-113. [CrossRef]

31. Wallace, A.; Mueller, R. Calcium uptake and distribution in plants. J. Plant Nutr. 1980, 2, 247-256. [CrossRef]

32. Hanger, B. The movement of calcium in plants. Commun. Soil Sci. Plant Anal. 1979, 10, 171-193. [CrossRef]

33. Villarino, G.H.; Mattson, N.S. Assessing tolerance to sodium chloride salinity in fourteen floriculture species. HortTechnology 2011, 21, 539-545. [CrossRef] 